inches in length. The granules had disappeared, leaving only minute spots of brown paler than the body. The third and fourth segments were still so little enlarged as to be noticed only by an entomologist. All the other marks were as before.

Fuly 12th.- The larvae grew to look dusty on the back, and stopped eating.

Fuly 15th.-Pupated. Pupa one and onehalf inches long, neither stout nor slender; very dark brown, and coffee-colored between the abdominal segments. Segments honeycombed; wing covers slightly rough; eye covers well defined. There was a slight pointed tubercle at the base of each antenna, close to the eye. Anal hook long, slender, with a bifid tip.

The second larva differed from this description in having much clearer and darker markings, and in being a trifle smaller. In the last moult it was at first bright green with dark green markings, but became brown twenty-four hours later. This one also spun a few threads fastening a leaf to the tin, while the first one did not spin at all. The pupa was a trifle smaller than the first one, and on January $14^{\text {th, }} \mathrm{I} 895$, at 2 P. M., gave a fine $\delta$ Amphion nessus.

\section{RHOPALOMERA XANTHOPS, SP. NOV.}

\section{BY S. W. WILLISTON, LAWRENCE, KANS .}

$\delta$, + Face wholly light yellow, with a small rounded tubercle near the middle. Palpi yellow, blackish at the proximal extremity. Antennae reddish yellow, the first two joints largely, and the third on the upper border, blackish. Front yellow, black or blackish on the anterior margin; no lateral frontal bristles; a pair of minute proclinate ocellar bristles present. Mesonotum reddish brown; when seen from in front with two distinct stripes reaching from the anterior border to about midway on the scutellum; a less distinct, median stripe, a narrow stripe on either side behind the suture, and the lateral margins in front, all opaque light yellow. Pleurae pitchy brown, mostly shining; a single mesopleural bristle present. Scutellum gently sulcate above, the distal half shining mahogany-colored. Abdomen black or deep reddish black; second, third, fourth and fifth segments each with the sides silvery white; between these spots there are two rows of similarly colored spots, becoming successively smaller, those of the second segment more or less coalescent with the lateral ones. Hypopygium black or pitchy black, shining. Legs pitchy black, the upper part of the femora more reddish; the immediate base of all the tibiae and the first two joints of all the tarsi light yellow; hind tibiae dilated and ciliated, the row of bristles not very strong and not implanted on tubercles. Wings strongly tinged with brown, which is more intense distally in front and about the cross-veins. Length ro-I I $\mathrm{mm}$.

Ten specimens, Yucatan, G. F. Gaumer, Coll. Univ. of Kans. It is possible that this species may be identical with the insufficiently described $R$. faviceps of Macquart, from New Grenada, but not probable, as there are positive discrepancies in the description of the head, thorax and abdomen. In several specimens the face is for the greater part blackish, probably the result of desiccation.

\section{Entomological Notes.}

In a paper read to the K. böhm. gesellschaft der wissenschaften on November 23d last, Dr. Anton Fritsch, of Prag, announced the discorery in the Permian beds of Bohemia of the larval cases of a caddis-fly. This is the first indication of the existence of insects with a complete metamorphosis in paleozoic times, unless the doubtful fragments found by Dathe in Silesian culm are to be regarded as shards of beetles, or the passages found in certain carboniferous woods are to be credited 
to coleopterous larvae. It is to be hoped that Dr. Fritsch will amply illustrate these remains in his great work now in progress on the Fauna der gaskohle Böhmens.

It is well to draw attention to two admirable brief illustrated papers published last year by Ch. Janet on Myrmica rubra, one on the morphology of the skeleton and especially of the posthoracic segment (Mém. soc. acad. de l' Oise, xv), the other on the anatomy of the petiole (Mém. soc. zool. France, 1894). We regret we have not space for a full analysis of each, but they will be found of great interest to morphologists and hymenopterists. The clear illustrations are pretty sure to find their way into text books.

The annual presidential address before the Entomological society of London by Capt. H. J. Elwes is on the geographical distribution of butterflies and deals largely with those of North America.

Dr. Ph. Bertkau announces that his health obliges him to give up the admirable annual review of entomology which has appeared in the Archiv für naturgeschichte since 1838 under different editors - Erichson, Schaum, Gerstaecker, Brauer and Bertkau. Entomologists are under great obligations to $\mathrm{Dr}$. Bertkau for the excellence of his summaries, their completeness and the promptness with which they have appeared. A still prompter method of rapid publication in all branches of biology is now being planned which is at the same time a practical combination of all the current reviews - a consummation devoutly to be wished and helped forward.

M. Emile Blanchard was retired November last from the chair of entomology at the Jardin des Plantes, on account of age; his first entomological paper was published nearly seventy years ago; his successor has not yet been announced.

Fire has committed ravages with our entomologists this winter. Mr. J. G. Jack lost his library and collection in Jamaica Plain by the destruction of the building in which they were kept; Prof. C. H. Tyler Townsend lost his valuable dipterological library (nearly complete for America and very full for Europe) by the burning of the warehouse at Las Cruces, N. Mex., while he was absent for a few weeks at Washington; and now comes news that Rev. C. J. S. Bethune's school at Port Hope, Ont., has been burnt to the ground; his loss is estimated at eighty thousand dollars.

Prof. C. H. T. Townsend's address is changed to Brownsville, Texas, where he is working for the entomological division of the U. S. Department of Agriculture. His correspondents should send him new sets of their publications.

\section{PROCEEDINGS OF THE CLUB.}

II January, I895. The I85th regular and I8th annual meeting (since incorporation) was held at 156 Brattle St. Mr. S. H. Scudder in the chair.

The annual reports of the officers were read and accepted.

In accordance with the recommendation of the executive committẹe it was voted that the treasurer be authorized to sell all the non-entomological and duplicate books now in the library, and such as may hereafter be acquired and apply the proceeds to the payment of the deficit on vol. 5 of Psyche until the same shall have been paid.

The following officers for 1895 were elected : President, C. M. Weed of Durham, N. H. ; secretary, R. Hayward; treasurer, S. Henshaw; librarian, S. H. Scudder; members at large of the executive committee, A. P. Morse and S. H. Scudder.

Mr. S. H. Scudder exhibited specimens of the cat-flea taken in Cambridge and two species of Scapteriscus taken in southern Florida by Mrs. A. T. Slosson and the late $\mathrm{Mr}$. Morrison. It is the first time this genus of mole crickets has been recognized within the limits of the United States; the species appeared to be closely allied to, but apparently distinct from $S$. mexicanum (Burm.) and $S$. abbreviatus Scudd., the latter a Brazilian species. 

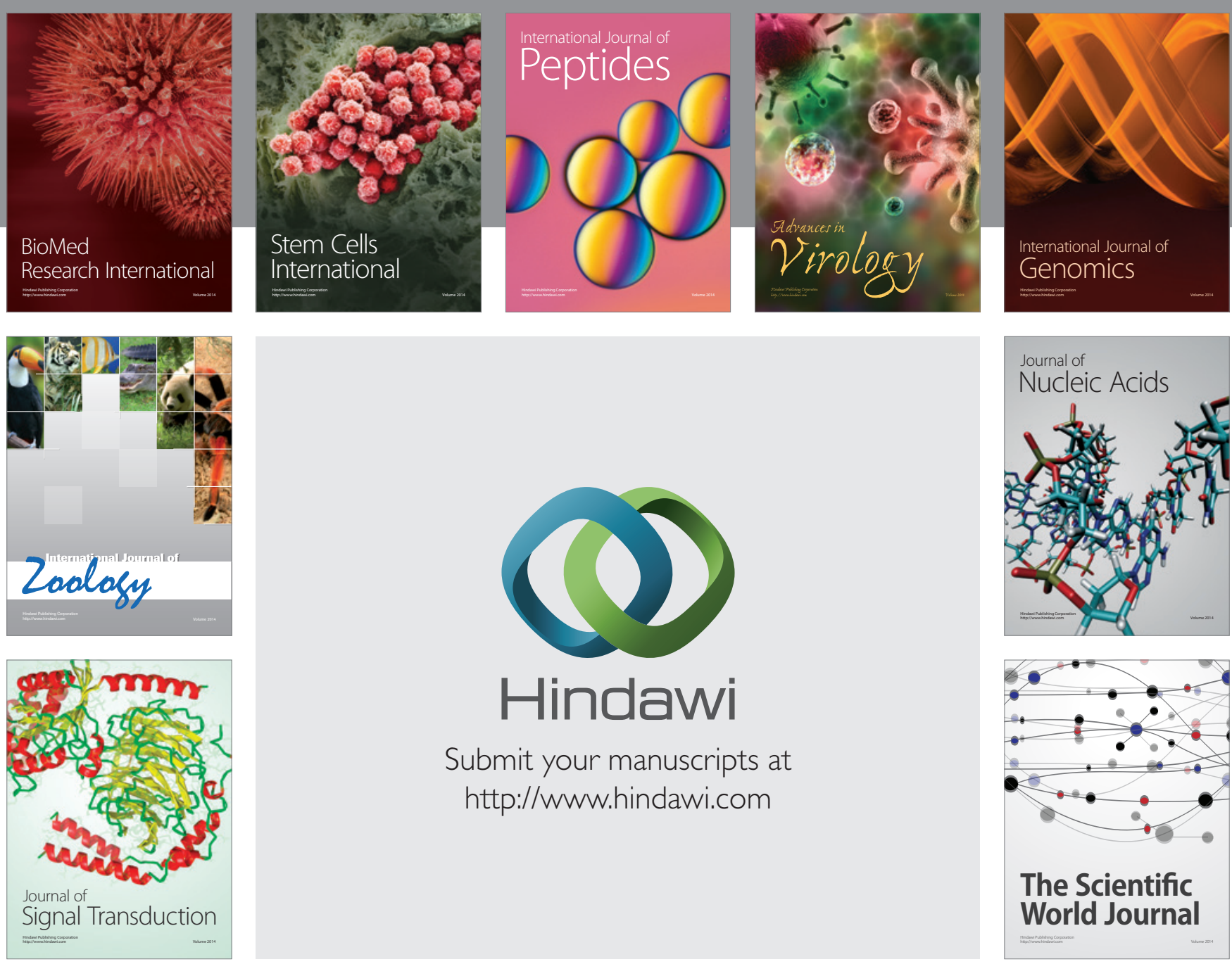

Submit your manuscripts at

http://www.hindawi.com
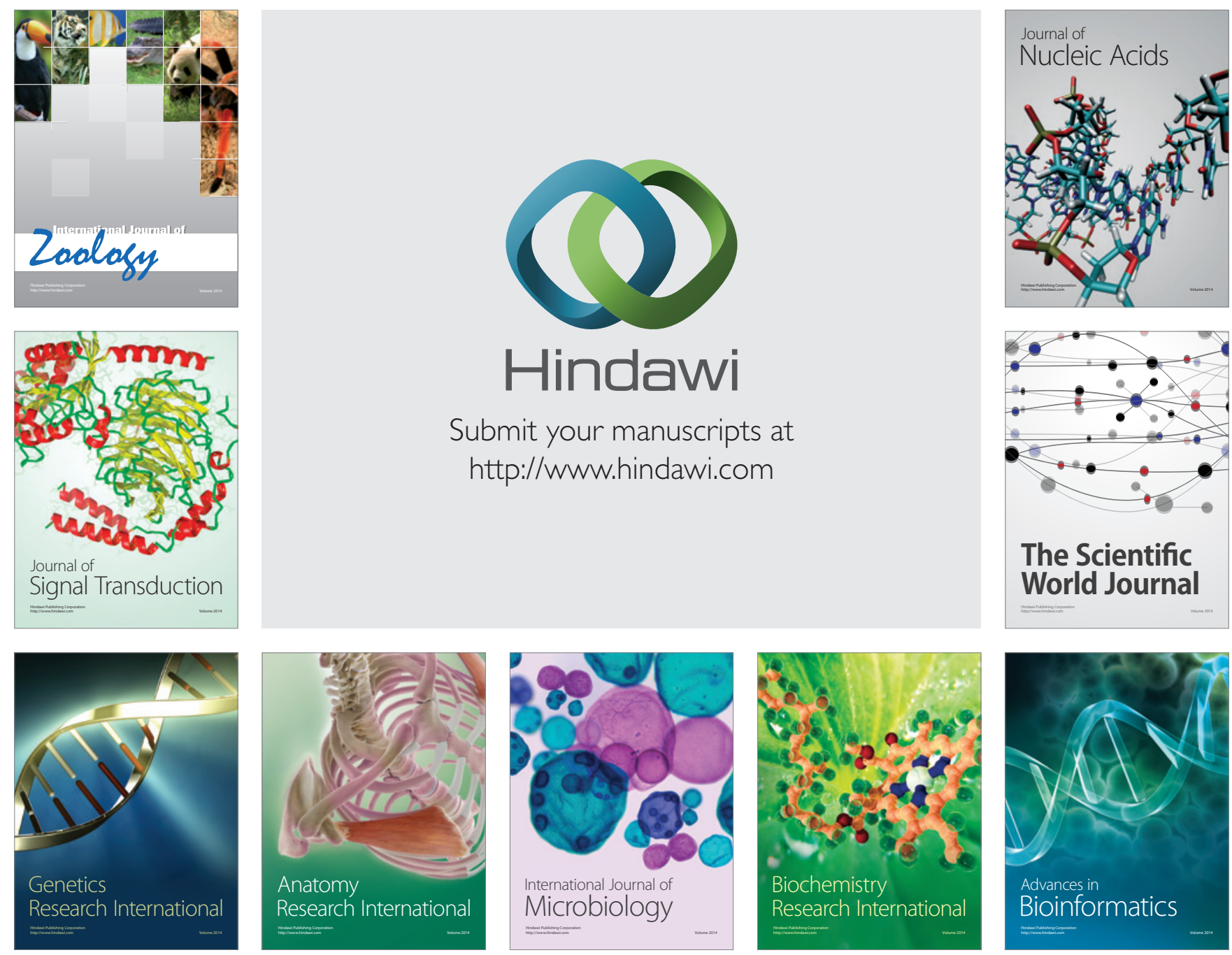

The Scientific World Journal
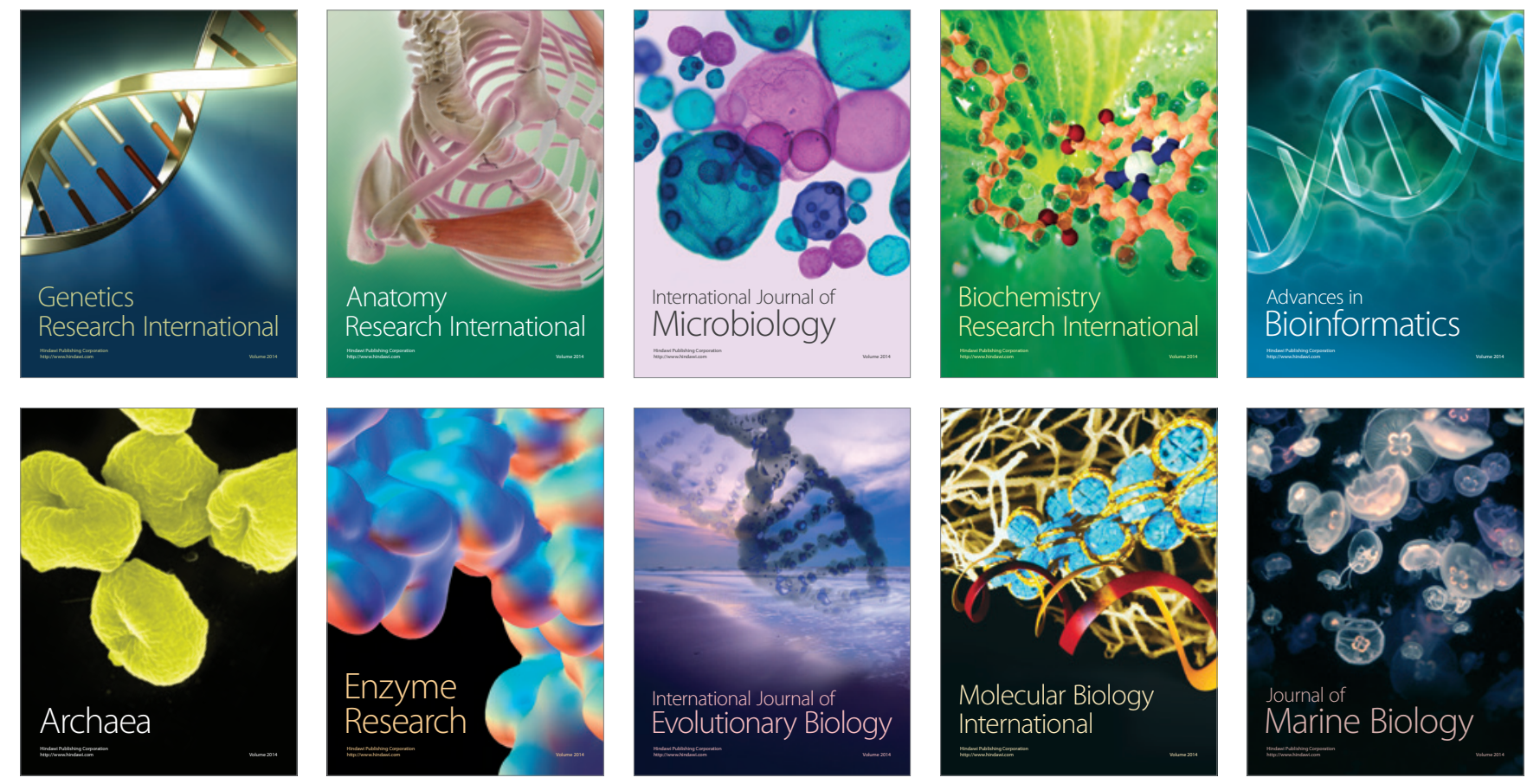